\title{
FAKTOR-FAKTOR YANG BERPENGARUH DALAM LUARAN KLINIS PASIEN TETANUS DI RSUP DR. MOHAMMAD HOESIN PALEMBANG
}

\author{
FACTORS AFFECTING THE CLINICAL OUTCOME OF TETANUS PATIENTS IN MOHAMMAD \\ HOESIN GENERAL HOSPITAL PALEMBANG \\ Luther Theng, * Theresia Christin, * Erial Bahar**
}

\section{ABSTRACT}

Introduction: Tetanus is a serious health problem with mortality rate up to $60 \%$ despite the decreasing incidence rate every year. Knowledge about factors affecting clinical outcome of tetanus patients may reduce mortality rate, better understanding on prevention and management of the disease. The clinical outcome

Aim: To know the incidence and factors that affect the clinical outcome of tetanus patients.

Method: Retrospective study with cross sectional analytic using hospital-based secondary data. Inclusion criteria were hospitalized tetanus patients within 3 years period (2013-2015) and complete medical record. Incidence, case fatality rate and other which other factors associated with clinical outcome were counted from medical record and analyzed by univariate and bivariate analysis, and logistic regression for multivariate analysis.

Result: The incidence rate of tetanus patients in 2013 was (4.28\%), 2014 (1.62\%), 2015 (2.87\%) and the mortality rate reaches $28.41 \%$. From 41 subjects, univariate, bivariate and multivariate analyses were performed. The four selected variables were gender, port d'entrée,-onset, and isolation room.

Dsicussion: Mortality rate reached $28.41 \%$ despite the decreasing incidence every year. Sex, port d'entrée, onset, and isolation room treatment are factors that affect clinical outcome of tetanus patients.

Keywords: Clinical outcome, mortality rate, tetanus

\section{ABSTRAK}

Pendahuluan: Tetanus merupakan masalah kesehatan serius dapat menyebabkan angka kematian mencapai $60 \%$ walaupun angka insiden semakin menurun setiap tahunnya. Pengetahuan mengenai faktor-faktor yang memengaruhi luaran klinis pasien dapat menurunkan angka kematian, upaya pencegahan penyakit dan keberhasilan penatalaksanaan.

Tujuan: Mengetahui insiden serta faktor-faktor yang memengaruhi luaran klinis pasien tetanus.

Metode: Studi bersifat retrospektif dengan metode potong lintang analitik dengan data sekunder berbasis RS. Kriteria inklusi adalah pasien tetanus yang dirawat sejak tiga periode 2013-2015 dan memiliki data rekam medis lengkap. Insiden, angka kematian dan hal-hal yang diperkirakan berhubungan dengan luaran ditelusuri dari rekam medis kemudian dilakukan analisis univariat, bivariat, dan multivariat menggunakan regresi logistik.

Hasil: Angka insiden tetanus tahun 2013 (4,28\%), 2014 (1,62\%), 2015 (2,87\%) dengan angka kematian rata-rata 28,41\%. Dari 41 subjek penelitian dilakukan analisis univariat, bivariat, dan multivariat. Empat variabel yang terpilih adalah jenis kelamin, port d'entrée, onset, dan perawatan pasien ruang isolasi.

Diskusi: Angka kematian kasus tetanus masih mencapai 28,41\% walaupun angka insiden semakin menurun setiap tahunnya. Jenis kelamin, port d'entry, onset, dan perawatan di ruang isolasi merupakan faktor-faktor berpengaruh terhadap luaran klinis pasien tetanus.

Kata kunci: Angka kematian, luaran klinis, tetanus

*Bagian Neurologi FK Universitas Sriwijaya/RSUP Dr. Mohammad Hoesin, Palembang; **Bagian Metodologi Penelitian FK Universitas Sriwijaya, Palembang. Korespondesi: dr.luther.theng@gmail.com.

\section{PENDAHULUAN}

Tetanus adalah penyakit pada susunan saraf yang ditandai dengan spasme tonik persisten disertai dengan serangan yang jelas dan keras. Penyakit ini merupakan toksemia akut akibat neurotoksin yang dihasilkan oleh Clostridium tetani dan ditandai dengan kekakuan secara keseluruhan dan kekejangan otot rangka. ${ }^{1-2}$ Tetanus merupakan salah satu penyakit infeksi yang dapat dicegah dengan imunisasi. Tetanus dapat terjadi pada orang yang belum diimunisasi, orang yang diimunisasi sebagian, atau telah diimunisasi lengkap tetapi tidak memperoleh imunitas yang cukup karena tidak melakukan booster secara berkala. ${ }^{3}$

Tetanus merupakan masalah kesehatan masyarakat dunia dengan insiden di seluruh dunia menurut WHO sekitar 700.000-1.000.000 kasus pertahun dan tingkat mortalitas $6-60 \%$. Angka ini menurun di Amerika setelah diperkenalkannya toksoid tetanus. Hampir semua kasus terjadi pada pasien yang 
belum pernah divaksinasi, atau sudah memenuhi seri primer namun belum mendapatkan booster setelah 10 tahun. $^{3}$

Pada tahun 1994, insiden tetanus di Indonesia adalah 0,2 per 100.000 populasi. Pada tahun 2005, kasus tetanus yang tercatat di RSCM adalah 11 kasus dengan kematian 27,3\%, meningkat pada tahun 2007 menjadi 18 kasus namun penurunan kematian menjadi 0\%. Di RS Harapan Kita pada tahun 2007 tercatat 5 kasus dengan 0 kematian. Data Dinas Kesehatan Propinsi Sumatera Selatan pada tahun 1994 menunjukkan bahwa kejadian tetanus di Sumatera Selatan adalah sebanyak 113 kasus, cukup banyak jika dibandingkan propinsi lain. ${ }^{3-4}$ Suatu penelitian pada tahun 2015 oleh Departemen Neurologi RSUP Dr. Mohammad Hoesin, Palembang didapatkan angka insiden kasus tetanus periode 1 Januari 201331 Desember 2014 di RSUP Dr. Mohammad Hoesin, Palembang sebesar 2,22\%. ${ }^{5}$

Diagnosis tetanus ditegakkan dengan mengeksklusi penyakitpenyebab kejang lainnya dan adanya luka yang menjadi tempat masuknya kuman tetanus. Tetanus dapat dikelompokkan berdasarkan derajat keparahan maupun lokasi gejalanya. Berdasarkan keparahan menurut Philips Score, tetanus terbagi menjadi derajat ringan, sedang, dan berat. Penilaian berdasarkan port d'entrée, masa inkubasi, imunisasi, dan faktor yang memberatkan. Adapun berdasarkan lokasi, dapat dibagi menjadi tetanus lokal, tetanus sefalik dan tetanus generalisata. ${ }^{6-8}$

Selain itu, luaran klinis pasien tetanus juga dipengaruhi oleh faktor sosiobiologis pasien seperti usia, jenis kelamin, indeks masa tubuh (IMT), pendidikan, pekerjaan, lokasi tempat tinggal, dan status imunisasi. ${ }^{9}$

Insiden tetanus saat ini sudah menurun, walaupun kisaran tertinggi angka kematian dapat mencapai angka $60 \%$. Penyakit ini masih belum dapat dimusnahkan meskipun sudah diterapkan pencegahan dengan imunisasi secara luas di seluruh dunia. Masih sedikit data penelitian mengenai pasien tetanus dan luaran klinis pasien tetanus dewasa di Indonesia, oleh karena itu perlu dilakukan penelitian untuk mengetahui faktor-faktor apa saja yang memengaruhi luaran klinis pasien tetanus ditinjau dari faktor klinis, sosiodemografis, dan faktor biologis.

\section{TUJUAN}

Mengetahui insiden tetanus serta faktor-faktor yang memengaruhi luaran klinis pasien tetanus di RSUP Dr. Moh. Hoesin, Palembang.

\section{METODE}

Penelitian potong lintang analitik menggunakan rekam medik pasien tetanus yang dirawat dalam rentang waktu 1 Januari 2013 hingga 31 Agustus 2016 di di bangsal rawat inap Neurologi, Bedah, dan Anak RSUP Dr. Mohammad Hoesin (RSMH), Palembang. Kriteria eksklusi jika data rekam medis tidak lengkap. Dilakukan penilaian indeks massa tubuh (IMT) pada subjek dan penggolongan menjadi 3 kategori, yaitu: kurus (IMT 17-18,5), normal (IMT 18,5-24,9), dan gemuk (IMT 25-29,9). ${ }^{10}$

Analisis bivariat dengan Chi-square untuk variabel dalam bentuk kategorik, sedangkan untuk variabel yang tidak memenuhi syarat Chi-square dilakukan penggabungan kategori pada variabel dan dilakukan uji Fisher. ${ }^{11-12}$ Tingkat hubungan antar variabel dinilai dengan rasio Odds (RO) dan tingkat kemaknaan $\mathrm{p}<0,05$. Analisis multivariat menggunakan analisis regresi logistik dengan metode bacward stepwise; variabel yang dimasukkan ke dalam analisis adalah variabel yang pada analisis bivariat mempunyai nilai $\mathrm{p}<0,25 .{ }^{12}$ Analisis statistik menggunakan software IBM statistics desktop versi 22.0 .

\section{HASIL}

Pada periode 1 Januari 2013 sampai 31 Agustus 2016 tercatat ada 88 pasien rawat inap dengan tetanus, namun hanya 41 subjek yang memenuhi kriteria penelitian. Insiden tetanus pada tahun 2013 adalah 37 dari 864 pasien rawat inap (4,3\%), tahun 2014 sebanyak 13 dari 801 (1,6\%), sedangkan tahun 2015 terdapat 25 dari 871 orang (2,9\%). Adapun dari 88 kasus tetanus tersebut, terdapat 25 pasien yang meninggal, sehingga angka kematiannya adalah $28,41 \%$.

Dari 41 subjek penelitian (Tabel 1), terbanyak adalah laki-laki $(80,5 \%)$ berusia $>30$ tahun $(43,9 \%)$, 
Tabel 1. Karakteristik Subjek Penelitian $(n=41)$

\begin{tabular}{|c|c|}
\hline Variabel & n (\%) \\
\hline \multicolumn{2}{|l|}{ Jenis kelamin } \\
\hline - Laki-laki & $33(80,5)$ \\
\hline - Perempuan & $8(19,5)$ \\
\hline \multicolumn{2}{|l|}{ Usia } \\
\hline - $<30$ tahun & $18(43,9)$ \\
\hline - 30-60 tahun & $15(36,6)$ \\
\hline - $>60$ tahun & $8(19,5)$ \\
\hline \multicolumn{2}{|l|}{ Indeks massa tubuh } \\
\hline - Kurus & $11(26,8)$ \\
\hline - Normal & $25(61)$ \\
\hline - Gemuk & $5(12,2)$ \\
\hline \multicolumn{2}{|l|}{ Pendidikan } \\
\hline - $\leq 9$ tahun & $17(41,5)$ \\
\hline - $>9$ tahun & $24(58,5)$ \\
\hline \multicolumn{2}{|l|}{ Suhu tubuh saat masuk } \\
\hline - $<38,5$ & $37(90,2)$ \\
\hline - $>38,5$ & $4(9,8)$ \\
\hline \multicolumn{2}{|l|}{ Status imunisasi } \\
\hline - Lengkap & $2(4,9)$ \\
\hline - Tidak pernah/tidak lengkap & $10(24,4)$ \\
\hline - Tidak diketahui & $29(70,7)$ \\
\hline \multicolumn{2}{|l|}{ Port d'entrée } \\
\hline - Internal/umbilikal & $1(2,4)$ \\
\hline - Kepala, leher, dan dinding tubuh & $17(41,5)$ \\
\hline - Ekstremitas proksimal & $6(14,6)$ \\
\hline - Ekstremitas distal & $15(36,6)$ \\
\hline - Tidak diketahui & $2(4,9)$ \\
\hline \multicolumn{2}{|l|}{ Jenis imunisasi } \\
\hline - ATS & $29(70,7)$ \\
\hline - HTIG & $12(29,3)$ \\
\hline \multicolumn{2}{|l|}{ Periode inkubasi } \\
\hline - $<10$ hari & $21(51,2)$ \\
\hline - $>10$ hari & $20(48,8)$ \\
\hline \multicolumn{2}{|l|}{ Onset } \\
\hline - $<48$ jam & $22(53,7)$ \\
\hline - $>48$ jam & $19(46,3)$ \\
\hline \multicolumn{2}{|l|}{ Antibiotik } \\
\hline - $\mathrm{Ya}$ & $41(100)$ \\
\hline - Tidak & $0(0)$ \\
\hline \multicolumn{2}{|l|}{ Penyakit penyerta } \\
\hline - Ada & $23(56,1)$ \\
\hline - Tidak ada & $18(43,9)$ \\
\hline \multicolumn{2}{|l|}{ Dirawat di ruang isolasi } \\
\hline - Ya & $24(58,5)$ \\
\hline - Tidak & $17(41,5)$ \\
\hline
\end{tabular}

dan memiliki IMT normal (61\%). Mayoritas subjek bertempat tinggal di luar Palembang (58,5\%) dan tidak pernah diimunisasi $(70,7 \%)$ dengan port d'entrée kepala, leher, dan dinding tubuh $(41,5 \%)$. Inkubasi yang diderita subjek kurang dari 10 hari $(51,2 \%)$ dengan onset kurang dari 48 jam $(53,7 \%)$. Seluruh subjek yang dirawat diberikan antibiotik $(100 \%)$, sebagian dirawat di ruang isolasi $(58,5 \%)$.

Usia, indeks massa tubuh, pendidikan, status imunisasi, dan port d'entrée dilakukan penggabungan kategori variabel, karena tabel tidak memenuhi syarat Chi-square. Pemberian antibiotik tidak dapat dilakukan uji Chi-Square karena tidak memiliki pembanding dengan kelompok yang tidak mendapatkan antibiotik. Nilai $\mathrm{p}$ yang didapatkan dari uji Fisher dilakukan pada variabel usia, IMT, suhu tubuh, status imunisasi, dan pemberian vaksin dikarenakan jumlah sampel yang relatif kecil. Didapatkan hubungan bermakna antara jenis kelamin, usia, suhu tubuh, port d'entrée, periode inkubasi, onset, dan perawatan di ruang isolasi yaitu dengan nilai $\mathrm{p}<0,05$ (Tabel 2).

Semua variabel terpilih (Tabel 2) dengan nilai $\mathrm{p}<0,25$ dianalisis secara bersama-sama dengan menggunakan metode backward stepwise. Analisis multivariat pada penelitian ini adalah ada empat variabel yang masih dipertahankan secara statistik yaitu jenis kelamin, port d'entrée, onset, dan perawatan pasien di ruang isolasi (Tabel 3).

\section{PEMBAHASAN}

Terdapat penurunan angka insiden kasus tetanus pada tahun 2015 (2,87\%) dibandingkan tahun 2013 (4,28\%). Penurunan ini sesuai dengan Tetanus Surveillance yang dilakukan di Amerika periode 2001-2008 dan penelitian Gunawan dkk di RS Hasan Sadikin Bandung. Hal ini dapat disebabkan oleh peningkatan pengetahuan masyarakat mengenai vaksinasi tetanus dan higienitas yang merupakan faktor risiko terjadinya tetanus setelah luka. ${ }^{4,13-18}$

Penelitian di Turki oleh Saltoglu dkk menjelaskan angka insiden tetanus tergantung pada lingkungan sosial, cuaca, dan kelembaban tanah. Prognosis tetanus tergantung dari infeksi nosokomial, imunisasi, penyakit penyerta, keparahan 
Tabel 2. Distribusi dan Hubungan Variabel Independen dengan Luaran Klinis (n=41)

\begin{tabular}{|c|c|c|c|c|}
\hline \multirow{2}{*}{ Variabel } & \multicolumn{2}{|c|}{ Luaran klinis n (\%) } & \multirow{2}{*}{$\mathbf{p}$} & \multirow{2}{*}{ RO } \\
\hline & Meninggal & Hidup & & \\
\hline \multicolumn{5}{|l|}{ Jenis kelamin } \\
\hline - Laki-laki & $10(30,3)$ & $23(69,7)$ & 0,04 & 0,145 \\
\hline - Perempuan & $6(75)$ & $2(25)$ & & \\
\hline \multicolumn{5}{|l|}{ Usia $^{\wedge}$} \\
\hline - $>60$ tahun & $6(75)$ & $2(25)$ & $0,04 *$ & 6,900 \\
\hline - $<60$ tahun & $10(30,3)$ & $23(69,7)$ & & \\
\hline \multicolumn{5}{|l|}{ IMT $^{\wedge}$} \\
\hline - Kurus & $6(54,5)$ & $5(45,5)$ & $0,287^{*}$ & 2,400 \\
\hline - Normal dan gemuk & $10(33,3)$ & $20(66,7)$ & & \\
\hline \multicolumn{5}{|l|}{ Pendidikan^^} \\
\hline - $\quad$ Rendah $(\leq 9$ Tahun $)$ & $7(58,3)$ & $5(41,7)$ & 0,161 & 3,111 \\
\hline - $\quad$ Tinggi (>9 Tahun) & $9(31)$ & $20(69)$ & & \\
\hline \multicolumn{5}{|l|}{ Pekerjaan $^{\wedge}$} \\
\hline - Petani dan buruh & $7(33,3)$ & $14(66,7)$ & 0,444 & 0,611 \\
\hline - IRT dan lain-lain & $9(45)$ & $11(55)$ & & \\
\hline \multicolumn{5}{|l|}{ Alamat } \\
\hline - Luar Palembang & $10(41,7)$ & $14(58,3)$ & 0,680 & 1,310 \\
\hline - Dalam Palembang & $6(35,3)$ & $11(64,7)$ & & \\
\hline \multicolumn{5}{|l|}{ Suhu tubuh awal } \\
\hline - $<38,5$ & $12(32,4)$ & $25(67,6)$ & $0,018^{*}$ & 0,324 \\
\hline - $>38,5$ & $4(100)$ & $0(0)$ & & \\
\hline \multicolumn{5}{|l|}{ Status imunisasi^ $^{\wedge}$} \\
\hline - Imunisasi tidak lengkap, tidak pernah dan tidakdiketahui & $16(41)$ & $23(59)$ & $0,512 *$ & 0,590 \\
\hline - Imunisasi lengkap & $0(0)$ & $2(100)$ & & \\
\hline \multicolumn{5}{|l|}{ Port d'entrée $e^{\wedge}$} \\
\hline $\begin{array}{l}\text { - Proksimal (kepala, leher, dinding tubuh, ekstremitas } \\
\text { proksimal, internal/umbilikal) }\end{array}$ & $13(54,2)$ & $11(45,8)$ & 0,018 & 5,515 \\
\hline - Distal (ekstremitas distal, tidak diketahui) & $3(17,6)$ & $14(82,4)$ & & \\
\hline \multicolumn{5}{|l|}{ Anti toksin (imunisasi) } \\
\hline - ATS & $11(37,9)$ & $18(62,1)$ & $0,999 *$ & 0,856 \\
\hline - HTIG & $5(41,7)$ & $7(58,3)$ & & \\
\hline \multicolumn{5}{|l|}{ Periode inkubasi } \\
\hline - $<10$ hari & $12(57,1)$ & $9(42,9)$ & 0,015 & 5,333 \\
\hline - $>10$ hari & $4(20)$ & $16(80)$ & & \\
\hline \multicolumn{5}{|l|}{ Onset } \\
\hline - $\quad<48$ jam & $14(63,6)$ & $8(36,4)$ & 0,001 & 14,875 \\
\hline - $>48 \mathrm{jam}$ & $2(10,5)$ & $17(89,5)$ & & \\
\hline \multicolumn{5}{|l|}{ Antibiotik } \\
\hline - $\mathrm{Ya}$ & $16(39)$ & $25(61)$ & - & - \\
\hline - Tidak & $0(0)$ & $0(0)$ & & \\
\hline \multicolumn{5}{|l|}{ Penyakit penyerta } \\
\hline - Ada & $11(47,8)$ & $12(52,2)$ & 0,192 & 2,383 \\
\hline - Tidak ada & $5(27,8)$ & $13(72,2)$ & & \\
\hline \multicolumn{5}{|l|}{ Ruang isolasi } \\
\hline - Tidak dirawat di ruang isolasi & $10(58,8)$ & $7(41,2)$ & 0,029 & 4,286 \\
\hline - Dirawat di ruang isolasi & $6(25)$ & $18(75)$ & & \\
\hline
\end{tabular}


Tabel 3. Variabel-variabel yang Terpilih dalam Model Analisis Multivariat

\begin{tabular}{|c|c|c|c|c|c|c|c|c|}
\hline \multirow[t]{2}{*}{ Variabel } & \multirow[t]{2}{*}{ B } & \multirow[t]{2}{*}{$S E$} & \multirow[t]{2}{*}{ Wald } & \multirow[t]{2}{*}{$D f$} & \multirow[t]{2}{*}{ Sig } & \multirow[t]{2}{*}{ RO } & \multicolumn{2}{|c|}{$\begin{array}{l}\text { IK 95\% } \\
E X P(B)\end{array}$} \\
\hline & & & & & & & Lower & Upper \\
\hline \multirow{5}{*}{$\begin{array}{l}\text { Jenis Kelamin } \\
\text { Port d'entrée } \\
\text { Onset } \\
\text { Perawatan ruang isolasi } \\
\text { Konstanta }\end{array}$} & $-2,524$ & 1,270 & 3,949 & 1 & 0,047 & 0,080 & 0,007 & 0,966 \\
\hline & 2,105 & 1,074 & 3,841 & 1 & 0,050 & 8,210 & 1,000 & 67,403 \\
\hline & 3,129 & 1,113 & 7,909 & 1 & 0,005 & 22,862 & 2,582 & 202,448 \\
\hline & 1,787 & 1,040 & 2,954 & 1 & 0,086 & 5,973 & 0,778 & 45,837 \\
\hline & $-2,443$ & 1,330 & 5,374 & 1 & 0,066 & 0,087 & & \\
\hline
\end{tabular}

B: Persamaan, SE: standar deviasi, Wald: Uji Wald, Df: degree of freedom, Sig: signifikansi, RO: rasio Odds, IK: interval kepercayaan, Lower: batas bawah, Upper: batas atas.

penyakit, dan keterlambatan pengobatan. ${ }^{19}$ Peneliti juga mengaitkan adanya faktor-faktor lain yang memengaruhi insiden tetanus seperti peraturan pemerintah di Indonesia mengenai sistem rujukan RS yang berjenjang sehingga dapat membuat keterlambatan penanganan pasien. Pasien tetanus yang berobat biasanya akan datang ke dokter praktek pribadi setempat yang kemudian akan dirujuk ke puskesmas terdekat, belum tentu tersedia imunisasi di wilayah tersebut menyebabkan penanganan pasien yang semakin lama.

Dibandingkan penelitian yang dilakukan oleh Centers for Disease Control and Prevention (CDC) mengenai Tetanus Surveilllance yang dilakukan di Amerika tahun 2001-2008, case fatality rate di Indonesia masih cukup tinggi, yaitu $13,2 \%$. Menurut penelitian Olubunmi dan Evelyn di RS tersier di Afrika, luaran penderita tetanus berupa angka kematian tergantung dari beberapa faktor yang dapat diidentifikasi, seperti periode inkubasi, waktu onset, keparahan penyakit, tempat masuknya kuman ke sistem saraf pusat, riwayat status vaksinasi dan keberadaan komplikasi otonom. ${ }^{20}$ Selain itu sistem rujukan berjenjang yang dicanangkan pemerintah (BPJS) dan ketersediaan anti toksin di faskes primer akan memperlambat penanganan pasien yang menyebabkan angka kematian masih cukup tinggi.

Penelitian ini mendapatkan kasus terbanyak pada laki-laki $(80,5 \%)$, oleh karena laki-laki lebih banyak terpapar faktor risiko. ${ }^{13-14} \mathrm{Hal}$ ini sesuai dengan hasil Ramachandra di India, bahwa laki-laki lebih banyak yang menderita tetanus dikarenakan bekerja sebagai petani dan perempuan lebih banyak mendapat vaksin tetanus selama kunjungan antenatal. ${ }^{21}$
Usia tertinggi kasus berada pada kelompok usia kurang dari 30 tahun (43,9\%), diikuti 30-60 tahun $(36,6 \%)$ dan lebih sedikit pada usia $>60$ tahun $(19,5 \%)$. Hasil penelitian ini berbeda dengan CDC 2014, bahwa sebanyak $49 \%$ penderita tetanus berusia $>50$ tahun. Pada penderita dengan riwayat imunisasi tetanus, individu berusia $>60$ tahun lebih berisiko terkena karena kadar antibodi berkurang dari waktu ke waktu. ${ }^{13}$ Saltoglu dkk menjelaskan bahwa seluruh laporan kematian tetanus terjadi pada pasien $>60$ tahun dikarenakan banyak penderita yang tidak mendapat imunisasi primer atau imunsiasi booster. ${ }^{19}$

Tidak ada hubungan antara IMT dan luaran pada penelitian ini dikarenakan IMT terbanyak pada subjek adalah IMT yang normal. Peneliti mengaitkan hal ini yang mungkin disebabkan oleh karena jumlah sampel yang kurang. Hasil penelitian ini berbeda dengan data pada tahun 2016 mengenai penurunan titer antibodi tetanus pada pasien dengan IMT gemuk/ overweight dikarenakan pada pasien yang gemuk terdapat peningkatan lean body mass, percent fat mass, dan penurunan $\mathrm{VO}_{2}$ (volume maksimal $\mathrm{O}_{2}$ ). ${ }^{22}$

Sebanyak $58,5 \%$ penderita bertempat tinggal di luar kota Palembang, dapat dihubungkan dengan lingkungan, pekerjaan, derajat keparahan tetanus, akses terhadap bantuan medis yang berbeda antara dalam kota dan luar kota Palembang termasuk ketersediaan ruang isolasi yang sangat diperlukan pada kasus tetanus yang dijumpai gejala kejang rangsang. ${ }^{9} 13-14$

Berdasarkan status imunisasi, sebanyak 70,7\% penderita berstatus imunisasi yang tidak diketahui, sementara $17,1 \%$ lainnya belum pernah imunisasi. Terdapat 2 penderita yang memiliki status imunisasi lengkap yaitu pada anak. Hal ini sesuai dengan 
teori bahwa vaksin tetanus sangat bermanfaat untuk pencegahan terjadinya tetanus. Sesuai pula dengan data CDC dan Gunawan. ${ }^{4,13}$ Pada penelitian Saltoglu dkk di Turki mengatakan salah satu faktor risiko terpenting yang menyebabkan tetanus adalah imunisasi primer. ${ }^{19}$

Pada penelitian ini terdapat subjek yang memiliki penyakit penyerta seperti diabetes melitus (56,1\%). Mekanismenya belum jelas menurut CDC, tetapi dianjurkan agar para klinisi mencurigai lebih awal jika pasien dengan penyerta diabetes yang datang dengan gangren. ${ }^{13-14}$

Berdasarkan port d'entrée, sebanyak 41,5\% penderita memiliki luka yang dipercayai merupakan port d'entrée pada kepala, leher, dan dinding tubuh. Sedikit berbeda dengan penelitian Gunawan bahwa paling banyak port d'entrée adalah pada kaki $(69,4 \%)$ diikuti ekstremitas atas $(33,3 \%)$, luka pada kepala (20\%), dan abdomen (2,2\% serta tidak diketahui port d'entrée-nya sebanyak 2,2\% pasien. ${ }^{4}$

Berdasarkan masa inkubasi, sebanyak $34,1 \%$ penderita memiliki masa inkubasi selama $<10$ hari $(51,2 \%)$ dan $>10$ hari sebanyak $48,8 \%$. Pada penelitian ini onset terbanyak $<48$ jam yaitu $53,7 \%$. Masa inkubasi dan onset berkaitan dengan derajat keparahan tetanus yang akan memengaruhi luaran., ${ }^{4,17}$

Berdasarkan obat-obatan yang diberikan, terdapat perbedaan persentase pada subjek yang mendapat imunisasi anti tetanus serum/ATS (70,7\%) dan Human Tetanus Imunoglobulin/HTIG $(29,3 \%)$, sedangkan pemberian antibiotik $100 \%$ yang disesuaikan dengan aturan yang berlaku di RSMH, Palembang. Terdapat perbedaan antara pasien yang mendapatkan immunoglobulin dan antitoksin tetanus. Pemberian imunisasi secara pasif dapat menetralisir toksin yang sedang bersirkulasi, namun terbatas untuk toksin yang telah berpenetrasi ke dalam sistem saraf. Pemberian dosis yang lebih besar tidak menunjukkan perbedaan. Ahmadsyah dan Sali menunjukkan bahwa metronidazole lebih efektif dibandingkan penisilin sebagai antibiotik. ${ }^{1,13,16,23-25}$

Sebanyak $41,5 \%$ subjek penelitian ini dirawat di ruang isolasi yang tidak dirawat di ruang isolasi, karena ada beberapa yang dirawat di ruang bedah, high care unit dan penuhnya ruang isolasi yang tersedia, yaitu hanya ada 2 di ruang saraf.

Luaran penelitian ini didapatkan 39\% subjek meninggal. Hasil ini menunjukkan bahwa mortalitas kasus tetanus di RSMH lebih tinggi dibandingkan RSCM tahun 2005 yaitu 27,3\% dan 25,6\% pada RSUP Dr. Hasan Sadikin, Bandung pada tahun 1991-1995. Demikian pula angka kematian pada tahun 2007 di RS Harapan Kita, yaitu hanya $0 \% .^{3-5}$ Temuan pada penelitian ini juga sedikit lebih tinggi dibandingkan temuan di Amerika, yaitu kematian pada tahun 2000 sebesar $30 \%$ dan menurun hingga $10 \%$ pada tahun 2007. ${ }^{13-14}$ Tingginya angka kematian akibat tetanus pada subjek-subjek ini dapat dihubungkan dengan derajat keparahan terutama derajat berat dan komplikasi yang dialami.

Kekurangan dalam penelitian ini adalah sampel yang kurang banyak dikarenakan tidak lengkapnya pencatatan dalam rekam medik megenai data sosisodemografi, faktor klinis, dan biologi sehingga diperlukan penelitian lebih lanjut dengan jumlah sampel yang lebih besar.

\section{KESIMPULAN}

Angka kematian kasus (case fatality rate) tetanus di RSUP Dr. Mohammad Hoesin, Palembang cukup tinggi, yaitu $28,41 \%$. Empat variabel yang bermakna secara statistik, yaitu jenis kelamin, port d'entrée, onset, dan perawatan di ruang isolasi.

\section{DAFTAR PUSTAKA}

1. Sudewi R. Sugianto P, Ritarwan K. Infeksi pada sistem saraf: tetanus. Surabaya: Pusat Penerbitan dan Percetakan Unair; Kelompok Studi Neuroinfeksi; 2011. h. 131-50.

2. Gelbart D. Tetanus. American Academy of Physician Assistants. 2017;30(12):46-47.

3. Satari HI, Chairulfatah A, Setiabudi D, Widhiani A, Amdani SK, Latupeirissa D, dkk. Penatalaksanaan tetanus pada anak. Health Technology Assessment Indonesia: Departemen Kesehatan Republik Indonesia; 2008.

4. Gunawan D. Tetanus in adults in Bandung. Neurol J Southeast Asia. 2006;I:43-6.

5. Yulianti I, Theodorus, Christin T. Angka kejadian tetanus di bangsal neurologi RSUP Dr. Mohammad Hoesin Palembang periode Januari 2013 - Desember 2014. FK UNSRI; 2015.

6. Ropper AH, Samuels MA, Klein JP. Adams and Victor's principles of neurology: disorders caused 
by bacterial toxins. Edisi ke-10. Mcgraw Hill Eduacation. 2014. h. 1215-7.

7. Sudoyo WA, Setiati S, Alwi I, Simadibrata M, Setiyohadi B, Fahrial A. Buku ajar ilmu penyakit dalam Jilid I. Edisi VI. Jakarta: Pusat Penerbitan Departemen Ilmu Penyakit Dalam FKUI; 2016.

8. Thwaites CL, Yen LM. Tetanus. Dalam: Kasper DL, Fauci AS, Hauser SL, Longo DL, Jameson JL, Loscalzo J. Harrison's principles of internal medicine. Edisi ke-19. New York: McGraw-Hill Education Medical; 2015. h. 984-7.

9. Disease I, Section E. Louisiana office of public health-infectious disease epidemiology sectioninfectious disease control manual. 2004;2748(504):813.

10. Departemen Kesehatan Republik Indonesia. Pedoman praktis memantau status gizi; 2011.

11. Dahlan SM. Langkah-langkah membuat proposal penelitian bidang kedokteran dan kesehatan. Jakarta: Sagung Seto. 2009. h. 99-110.

12. Dahlan SM. Statistik untuk kedokteran dan kesehatan deskriptif, bivariat, dan multivariat. Epidemiologi Indonesia. Jakarta: Sagung Seto. 2014. h.16-17, 2459.

13. Mootrey G, Tiwari T, Weinbaum C. Tetanus. CDC. 2013;2013:341-51

14. CDC. Tetanus surveillance - United States, 2001-2008. MMWR Morb Mortal Wkly Rep. 2011;60(12):365-9.

15. Gibson K, Bonaventure UJ, Kiviri W, Parlow J. Case reports: tetanus in developing countries: a case series and review. Canadian J Anesthesiol. 2009;56:307-15.
16. Lisboa T, Ho YL, Filho GTH, Brauner JS, Valiatti $\mathrm{JL}$, Verdeal JC, dkk. Guidelines for the management of accidental tetanus in adult patients. Rev Bras Ter Intensiva. 2011;23(4):394-409.

17. Khaskheli MS, Khuhro BA, Jamali AH. Tetanus: still a killer in adults. Anaesth Pain \& Intensive Care. 2013;17(2):149-53.

18. Miranda FDB, Ximenes RAA, Barone AA, Vaz VL, Vieira AG, Albuquerque VMG. Clinical classification of tetanus. Braz Medical Biol Res. 2006;39:1329-37.

19. Saltoglu N, Tasova Y, Midikili D, Burgut R, Dundar HI. Prognostic factors affecting death from adult tetanus. Clin Mirobiol Infect. 2004;10:229-33.

20. Ognurin OA. Olubunmi, Unuigbe EI. Tetanus: an analysis of the prognosticating factors of cases seen in tertiary hospital developing African country between 1990 and 2000. Tropical Doctor. 2004;34:240-24.

21. Ramachandra L, Shobha KL, Kannan AP. A retrospective clinical study on the factors which affected tetanus. Internet J Microbiol. 2008;7(1).

22. Eliakim A, Swindt C, Zaldivar F, Casali P, Cooper M. Reduced tetanus antibody titers in overweight children. HHS Public Access. 2006;39(2):137-41.

23. Farrar JJ, Yen LM, Cook T, Fairweather N, Binh N, Parry J. Neurological aspects of tropical disease: tetanus. J Neurol Neurosurg Psychiatry. 2000;69:292_ 301.

24. Thwaites CL. Tetanus. Practical Neurol. 2002;3:1307.

25. Dittrich KC, Keilany B. Tetanus: lest we forget. Canadian J Emergency Medicine. 2001;3 (1):47-50. 